$\begin{array}{lr}\text { Ester } & \boldsymbol{K} \\ \text { Methyl } & 20 \cdot 4 \\ \text { Ethyl } & 18 \cdot 5 \\ \text { Propyl } & 12 \cdot 4 \\ \text { Butyl } & 11 \cdot 4 \\ \text { Amyl } & 9 \cdot 8\end{array}$

At the same time, the logarithmic increase in 'biological' adsorption $(B)$, plotted against chain-length (Curve III), agrees very much better with the simple physical determination (Curve II).

Since inhibition seems likely to be more closely related to the number of molecules adsorbed than to the area they occupy, it would seem profitable to examine the slope values regarded as $A / K_{2}$ (equation $7 a)$. Without losing sight of the possibility of decreased $K_{2} / A$ being due to a decrease in effectiveness per molecule $\left(K_{2}\right)$, a more reasonable proposition for such a homologous series would be that it results from increasing $A$ due to extra molecular bulk or a different disposition relative to the adsorbed surface.

It needs to be observed at this point, however, that other inhibitor/organism relationships need not be so straightforward as that quoted above. At least two reasons can contribute to this: (i) the accurate determination of the constants is often difficult; (ii) the dosage/response relationship is, to a varying degree, only approximated by the simple adsorption form, and it might be necessary to restrict the determination of constants to a relatively small portion of the curve such that permits valid comparison between substances. With these reasonable provisos, data for $P$. roqueforti and $A$. niger seem to show at least the same trends as those seen clearly in B. fulva. Their detailed examination will be dealt with elsewhere in collaboration with $\mathrm{Mr}$. G. W. K. Cavill.

In conclusion, we should like to express our indebtedness to Prof. C. N. Hinshelwood for his critical comment on an earlier draft of the ideas set out in the present communication. Needless to say, although the present form has been influenced by such comments, Prof. Hinshelwood cannot be held responsible for any of its residual imperfections.

'Vincent, J. M., J. Soc. Chem. Ind., 66, 149 (1947) ; Cavill, G. W. K., and Vincent, J. M., ibid., 66, 175 (1947).

"Hinshelwood, C. N., "The Chemical Kinetics of the Bacterial Cell" (Clarendon Press, Oxford, 1946).

${ }^{3}$ Wilson, P. W, chapter in "Respiratory Enzymes" (University of Wisconsin Biochemists, Burgess Publishing Co., 1939).

4Adams, R., Rideal, E. K. et al., J. Amer. Chem. Soc., 48, 1758 (1926) .

\section{NITROGENOUS CONSTITUENTS OF THE POTATO}

\author{
By Dr. E. B. SLACK \\ Biochemical Laboratory, Cambridge
}

$\mathrm{O}^{\mathrm{s}}$ SBORNE and Campbell ${ }^{1}$ isolated a globulin from the expressed sap of minced potatoes. By extracting the crushed potato residue with 10 per cent sodium chloride, they were able to obtain an additional amount of protein which they considered was identical with the globulin contained in the press juice. When a solution of this protein in 10 per cent sodium chloride was gradually heated, a flocculent coagulum was formed at about $60^{\circ} \mathrm{C}$., and further precipitates were obtained at higher temperatures up to $80^{\circ} \mathrm{C}$. At this temperature coagulation of all the protein was complete, although a minute amount of proteose material appeared to remain in solution. The authors concluded that the only true protein present in potato was a globulin, with rather indeterm- inate heat-coagulation properties, for which they proposed the name of 'tuberin'. Neuberger and Sanger ${ }^{2}$ extended this work and found that the potato residue, after removal of the press juice, contained a small amount of nitrogen (about 8 per cent of the total potato-nitrogen) which was insoluble in all the usual protein solvents. In more recent studies on tuberin, Groot, Janssen, Kentie, Oosterhius and Trap $^{3}$ have shown that it can be separated electrophoretically into two components.

Determinations of the amino-acid content of tuberin were carried out by Sjollema and Rinkes ${ }^{4}$ and by Groot ${ }^{5}$. The results of the earlier workers are probably not very reliable owing to the inadequacy of methods at that time. It is noteworthy, however, that Groot's recent figure for the lysine content of tuberin is of the same low order, $3 \cdot 6$ per cent, as that obtained by the earlier workers.

Using Gale's decarboxylase method $^{6}$, I have found that a sample of tuberin, prepared from King Edward potatoes by heat coagulation of the press juice at $80^{\circ}$ and $p H 4.5$, had a lysine content of $7 \cdot 7$ per cent, a value that is more consistent with the high nutritive value of tuberin reported by Kon ${ }^{7}$ and by Chick and Cutting ${ }^{8}$. Estimations of the other essential aminoacids of tuberin were made by the methods of Tristram ${ }^{9}$ for valine, leucines, tyrosine and phenylalanine, of Macpherson ${ }^{10}$ for arginine and histidine, of Lugg ${ }^{11}$ for cystine and methionine, of Hess and Sullivan ${ }^{12}$ for tryptophan, and of Rees ${ }^{13}$ for threonine. The results show that the only amino-acid present in inadequate amount is methionine (see accompanying table). In addition to tuberin, the potato contains a variety of other nitrogenous substances present in considerable amount, the actual ratio of protein to non-protein nitrogen varying appreciably with different samples. In the case of the King Edward potatoes used in the present work, about half to two-thirds of the total nitrogen was non-protein.

\begin{tabular}{|c|c|c|}
\hline \multicolumn{3}{|c|}{ AMINO-ACID COMPOSITION OF TUBERIN AND OF WHOLE POTATO } \\
\hline Amino-acid & $\begin{array}{c}\text { Amino-acids (gm.) pe } \\
\text { Whole potato }\end{array}$ & $\begin{array}{l}16 \mathrm{gm} \text {. nitrogen in } \\
\text { Tuberin }\end{array}$ \\
\hline Phenylalanine & $5 \cdot 4$ & 6.6 \\
\hline Leucines & $11 \cdot 3$ & $17 \cdot 5$ \\
\hline Valine & $4 \cdot 8$ & $6 \cdot 1$ \\
\hline Tryptophan & 0.8 & 1.6 \\
\hline Threonine & $3 \cdot 7$ & $5 \cdot 9$ \\
\hline Arginine & $4 \cdot 4$ & $6 \cdot 0$ \\
\hline Histidine & $1 \cdot 7$ & $2 \cdot 2$ \\
\hline Lysine & $5 \cdot 0$ & $\overline{7} \cdot \overline{7}$ \\
\hline Cystine & $1 \cdot 7$ & $2 \cdot 1$ \\
\hline Methionine & $1 \cdot 6$ & $\overline{2} \cdot \hat{3}$ \\
\hline
\end{tabular}

Neuberger and Sanger ${ }^{2}$ and Chick and Cutting ${ }^{8}$ examined the non-protein fraction and found that about 50 per cent of the nitrogen was present in the form of amides (glutamine and asparagine), and about 30 per cent in the form of nitrogenous bases precipitable by phosphotungstic acid. Only about 10-20 per cent of the non-protein nitrogen was found to be present in the form of $\alpha$-amino-acids. In the present work, this $\alpha$-amino fraction has been separated by the procedure of Vickery ${ }^{14}$ and analysed for the essential amino-acids by the methods specified for tuberin above. By combining the values obtained for the amino-acid content of the non-protein fraction with those found for tuberin, and assuming that all the protein present in potato has the same composition as tuberin, it is possible to calculate the amino-acid composition of the 'crude-protein' $(\mathrm{N} \times 6)$ of the whole potato. The result is given in the table, and shows that the latter is poorer in its content of all the essential amino-acids than tuberin, from which it might be predicted that its nutritive value would also be inferior to that of tuberin. 


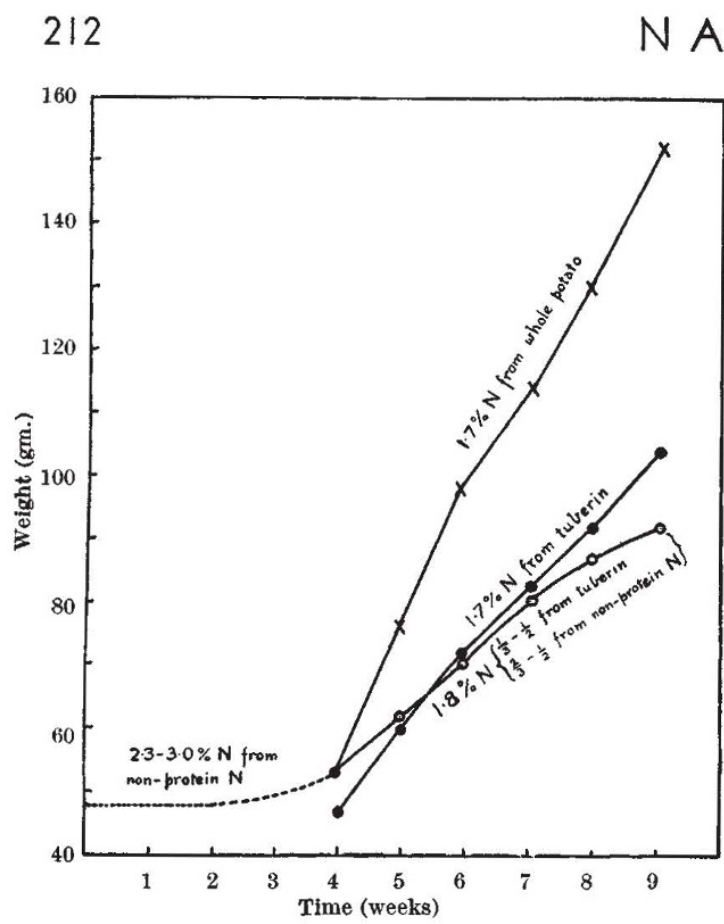

THE AVERAGE GROWTH-RATES OF YOUNG LITTER-MATE RATS RECEIVING DIETS COMPLETE WITH RESPECT TO ALL ESSENTIA NOTRIRNTS FXOEPT PROTHIN, SHOWING THE RELATIVE NUTRITTV VALUE OF VARIOUS NITROGENOUS CONSTITUENTS OF THE POTATO

Chick and Cutting ${ }^{8}$ and Chick and Slack ${ }^{15}$ have shown, however, that although the non-protein fraction is alone incapable of supporting growth, yet the mixture of protein and non-protein nitrogen in the whole tuber possesses a nutritive value, as measured by its growth-supporting capacity for young rats, at least equal to that of the isolated tuberin. The obvious explanation of this result is not possible, since no supplementation between tuberin and the non-protein nitrogen could be demonstrated when the two fractions were isolated and fed in various proportions. In the accompanying growth charts, obtained in one such experiment, the broken line represents the average weight-change of a group of six litter-mate weanling rats receiving a diet complete with respect to all essential nutrients except nitrogen. The latter was derived entirely from protein-free potato juice and fed at a level of $2 \cdot 3$ per cent nitrogen on the dry weight for three weeks and at a level of 3.0 per cent nitrogen for a further week. There was little change in weight on these diets. At the end of a month, three of the six rats were given a diet containing 1.7 per cent nitrogen derived from whole potato, and the other three a diet containing 1.8 per cent nitrogen derived from a mixture of tuberin and non-protein nitrogen in the proportions in which they occur in the whole potato. The average growth-curve of a group of three rats receiving a diet in which all the nitrogen is supplied at a level of 1.7 per cent nitrogen derived entirely from tuberin is included from another experiment.

It is difficult to account in terms of amino-acid content for the superiority of the whole potato over tuberin as a source of dietary nitrogen. The small amount of unidentified nitrogen which cannot be extracted from potato residue (about 8 per cent of the total potato nitrogen and almost certainly protein) may be exerting an effect, or the potato may contain minute amounts of material similar to streptogenin, which Woolley ${ }^{16}$ has shown to be a peptide-like factor
February 7, 1948 vol. 161

stimulating the growth of $L$. Casei and obtained by tryptic digest of certain proteins of which it is an integral part. Otherwise it would appear that the potato contains further substances which, though neither proteins nor amino-acids, are capable of replacing or supplementing these in the diet.

I wish to thank Dr. Harriette Chick for permitting me to include the results of the experiments shown in the graph, and should also like to record my appreciation of the helpful advice and encouragement I have received from Sir Charles Martin and Prof. A. C. Chibnall.

${ }^{1}$ Oshorne, T. B., and Campbell, G. F., J. Amer. Chem. Soc., 18, 575 (1896).

2 Neuberger, A., and Sanger, F., Biochem. J., 36, 862 (1942)

${ }^{3}$ Groot, E. H., Janssen, L. W., Rentie, A., Oosterhius, H. K., and Trap, H. J. L., Voeding, 6, 124 (1946).

- Sjollema, B., and Rinkes, I. J., Hoppe-Seyler's Z. physiol. Chem. 76, 369 (1912).

- Groot, E. H., Voeding, 6, 153 (1945).

- Gale, E. F., Nature, 157, 263 (1946).

'Kon, S. K., Biochem. J., 22, 261 (1928).

${ }^{8}$ Chick, H., and Cutting, M. E. M., Lancet, ii, 667 (1943).

- Tristram, G. R., Biochem. J., 40, 721 (1946).

${ }^{10}$ Macpherson, H. T., Biochem. J., 40, 470 (1946).

${ }^{11}$ Lugg, J. W. H., Biochem. J., 32, 2114 (1938).

12 Hess, W. C., and Sullivan, M. X., Ind. Eng. Chem., Anal. Ed. (November 1945)

1s Rees, M. W., Biochem. J., 40, 632 (1946).

14 Vickery, H. B., J. Biol. Chem., 65, 657 (1925).

${ }^{18}$ Chick, H., and Slack, E. B., unpublished work (1944).

16 Woolley, D. W., J. Biol. Chem., 162, 383 (1946).

\section{NEW CHEMICAL AND PHYSICAL LABORATORY AT THE ROYAL AIRCRAFT ESTABLISHMENT, FARNBOROUGH, HANTS}

YHEMICAL research in the Royal Aircraft Estab. $\mathcal{A}$ lishment commenced under Dr. J. E. Ramsbottom in the early years of the First World War, but until very recently the accommodation for chemical and physical research was by no means adequate for present-day needs. However, a new laboratory has recently been completed and was formally opened on October 29 by Mr. G. R. Strauss, Minister of Supply. In his introductory address, the director of the Royal Aircraft Establishment, Mr. W. G. A. Perring, outlined the growth of chemistry at the Establishment and summarized the outstanding contributions of the Chemistry Department to aeronautical research. A specification for a new laboratory was originally drawn up by Dr. Ramsbottom and his staff before the Second World War, and in his capacity of war-time head of the Chemistry Department, Prof. W. F. K. Wynne-Jones was responsible for the detailed layout of the laboratory and for pressing forward the extended scheme. Much valuable advice was received from Sir Ian Heilbron of the Imperial College of Science and Technology, London, and throughout the planning and constructional period Mr. R. B. Twiss, a member of the Chemistry Department staff, has been the general adviser on all research requirements to the architect, Mr. Oliver Law, the consulting engineers, Messrs. A. H. Barker and Partners, and the contractors, Messrs. Trollope and Colls.

The new laboratory was designed in 1944 and constructed during the period 1945-47. Its general layout represents an attempt to provide up-to-date facilities for both basic research in the chemical and 